\title{
The Effect of Salbutamol Controlled Release on Bronchial Hyperresponsive- ness in Patients with Bronchial Asthma
}

\author{
Hadiarto Mangunnegoro, Faisal Yunus, Yulino Amrie
}

\begin{abstract}
Abstrak
Derajat kepekaan trakeobronkial dapat diukur dengan melakukan uji provokasi bronkus. Makin berat derajat hiperreaktivitas bronkus makin berat serangan asma yang ditimbulkan. Pengukuran kepekaan saluran napas dilakukan menurut cara Cockroft. PC 20 adalah parameter yang paling sering digunakan untuk menentukan besarnya kepekaan saluran napas yaitu dosis zat inhalasi yang menyebabkan penurunan volume ekspirasi pasca detik pertama $\left(V E P_{1}\right)$ sebesar $20 \%$. Tujuan penelitian ini adalah untuk menyelidiki pengaruh salbutamol lepas terkendali terhadap derajat hiperreaktivitas bronkus. Pada 20 orang penderita asina dewasa diukur besarnya hiperreaktivitas bronkus dengan memberikan provokasi inhalasi larutan metakolin untuk mendapatkan nilai $P C_{20}$ dan $P D_{20}$. Pemeriksaan dilakukan sebanyak 5 kali yaitu 2 kali pada waktu "run in" dan masing-masing 1 kali setelah 2 dan 4 minggu masa pengobatan serta 2 minggu setelah obat dihentikan. Dari penelitian ini didapatkan $P C_{20}$ meningkat setelah pemberian salbutamol lepas terkendali

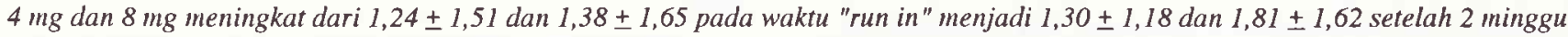
pengobatan serta 1,88 $\pm 1,58$ dan 1,49 $\pm 1,71$ setelah 4 minggu pengobatan. Setelah 2 minggu pengobatan dihentikan nilai $P C_{20}$ pada kedua kelompok menurun menjadi 1,33 $\pm 1,26$ dan 1,29 $\pm 1,21$. Tetapi kenaikan dan penurunan nilai PC 20 ini secara statistik tidak bermakna. Disimpulkan bahwa pemberian salbutamol lepas terkendali selama 4 minggu pada penderita asma yang diteliti tidak bermanfaat untuk menurunkan hiperreaktivitas bronkus.
\end{abstract}

\begin{abstract}
Bronchial provocation test is a measure of tracheobronchial sensitivity, where the increasing degree of bronchial hyperresponsiveness corresponds to the severity of the asthmatic attack. The method of Cockroft is used to measure the sensitivity of the respiratory tract, and the most frequently used parameter is $P_{2}$, which measures the inhalation dose causing a $20 \%$ decrease in the expiration volume after the first second $\left(F E V_{1}\right)$. The aim of this study is to investigate the effect of controlled release salbutamol on bronchial hyperresponsiveness. Twenty adult asthmatic patients were provocated by the inhalation of metacholine solution and their bronchial hyperresponsiveness were measured to get the $P C_{20}$ and $P D_{20}$ values. Measurements were conducted 5 times, 2 times at the run in period, once at the 2 nd and 4 th week of treatment, and once at the 2 nd week after treatment. The result of this study showed an increase in $P_{20}$ in patients treated by $4 \mathrm{mg}$ and $8 \mathrm{mg}$ controlled release salbutamol $(1.24 \pm 1.51$ and $1.38 \pm 1.65$ at the run in period, were increased to $1.30 \pm 1.18$ and $1.81 \pm 1.62$ at the 2 nd week of treatment, and to $1.88 \pm 1.58$ and $1.49 \pm 1.71$ at the 4 th week of treatment respectively). Two weeks after the treatment was stopped, the $P C_{20}$ values of both treatment groups were decreased to $1.33 \pm 1.26$ and $1.29 \pm 1.21$. These increase and decrease in $P C_{20}$ values were statistically not significant, so we concluded that a 4 weeks administration of controlled release salbutamol asthmatic patient is not effective in reducing bronchial hyperresponsiveness.
\end{abstract}

Keywords : Bronchial provocation test, Salbutamol controlled release, Bronchial asthma

\section{INTRODUCTION}

Asthma is a clinical syndrome, characterized by an increase in tracheobronchial response to various stimuli. ${ }^{1}$ This sensitivity is known as bronchial hyperresponsiveness. The major manifestation of bronchial hyperresponsiveness is airway obstruction, and histologically manifested as oedema of the bronchial mucosa, inflamatory cells (especially eosinophil) infiltration, bronchial epithelium damage, and mucous obstruction of the periferal airway. ${ }^{1,2}$

Bronchial hyperresponsiveness is increased considerably by respiratory tract inflamation. ${ }^{3,4,5}$ Bronchial inflamation in asthma is a very specific inflamation characterised by massive infiltration of limphocyte and eosinophil to the bronchial mucosa and 
submucosa. Corticosteroids are very effective in inhibiting and reducing the bronchial hyperresponsiveness. ${ }^{4}$

Salbutamol is a $\beta_{2}$ agonist widely used in the treatment of asthma. Various investigators have reported different results about the effect of salbutamol on bronchial hyperresponsiveness. ${ }^{2,4,5,6,7}$ In Indonesia, there is no data about the effect of salbutamol controlled release on bronchial hyperresponsiveness.

The aim of this study is to investigate the effect of salbutamol controlled release on bronchial hyperresponsiveness in stable asthmatic patients.

\section{MATERIALS AND METHOD}

Twenty adults aged $16-45$ years, with chronic asthma, treated in the Persahabatan Hospital, were included in this study.

Inclusion criteria for the study group were: patients with a history of asthma, without other lung disease, heart disease, diabetes mellitus and thyrotoxicosis; not pregnant; having first second forced expiration volume $\left(\mathrm{FEV}_{1}\right)$ more than $1000 \mathrm{ml}$ or $65 \%$ of the supposed value; 2 months before this study were free from respiratory tract infection, or acute exaxerbation; bronchodilator test showed a $20 \%$ increase or more in $\mathrm{FEV}_{1}$.

The patients were kept from inhalating bronchodilators 10 hours, from taking $\beta_{2} 8$ hours, and from taking slow release theophyline 24 hours before the examination, while the usual doses of corticosteroid were continued.

The lung function and bronchial provocation test were performed on each visit, ie. at the run in period, second and fourth week of treatment, and 2 weeks after the treatment was over. The lung function was tested using a "chest corporation Japan" made, HI 298 microspirometer. The bronchial provocation test was performed using various concentration of metacholine solution as provocating agent. The concentrations of metacholine used were $49 \mu \mathrm{g} / \mathrm{ml}, 98 \mu \mathrm{g} / \mathrm{ml}, 195 \mu \mathrm{g} / \mathrm{ml}$, $390 \mu \mathrm{g} / \mathrm{ml}, 781 \mu \mathrm{g} / \mathrm{ml}, 1.563 \mu \mathrm{g} / \mathrm{ml}, 3.125 \mu \mathrm{g} / \mathrm{ml}, 6.25$ $\mathrm{mg} / \mathrm{ml}, 12.5 \mathrm{mg} / \mathrm{ml}$ and $25 \mathrm{mg} / \mathrm{ml}$.

Provocation test according to Cockroft method, was done to measure the $\mathrm{PC}_{20}$, using a 'Japan Chest Corporation' made Astograph TCK $6000 \mathrm{M}$. First the FEV $_{1}$ was measured three times, and the highest value was recorded, followed by the inhalation of control solution (phisiologic salt) for 2 minutes. Thirty and 90 minutes after the inhalation, the $\mathrm{FEV}_{1}$ was measured again. The test was continued, when the lowest FEV 1 measured after the inhalation of control solution did not differ more than $100 \mathrm{ml}$ compared to the FEV 1 measured before the inhalation. The continuation was done 5 minutes after, by the inhalation of the lowest concentration of metacholin solution $(49 \mu \mathrm{g} / \mathrm{ml}$ for 2 minutes), followed by the measurement of FEV 1 . Succesive metacholin inhalation using higher concentrations was done, until the decrease of the lowest FEV after inhalation was more than $20 \%$ compared to the $\mathrm{FEV}_{1}$ after the inhalation of control solution. The metacholin dose causing the $20 \%$ decrease in $\mathrm{FEV}_{1}$ was regarded as the $\mathrm{PC}_{20}$ (cited from Wiwien et al, 1990). ${ }^{8}$

Measurements of $\mathrm{PC}_{20}$ were done 5 times. Four or $8 \mathrm{mg}$ controlled release salbutamol (Volmax ${ }^{\mathrm{R}}$ ) was administered twice a day, in the morning and at night, for 4 weeks. Trials were done at random and double blind.

Statistical analysis using 2 way anova and Student's t test was performed to compare the two groups of treatment.

\section{RESULT}

Twenty asthmatic patients (10 men and 10 women) aged 16-45 years (mean: $25.2 \pm 8.5$ years) were included in this study. The patient's characteristics were shown in table 1 .

Eight of the patients were in the $4 \mathrm{mg}$ and 12 were in the $8 \mathrm{mg}$ salbutamol group.

To assess the reproducibility of the $\mathrm{PC}_{20}$ value before treatment, bronchial provocation test were done twice at a 2 weeks interval, in the run in period. Statistically, in each group the $\mathrm{PC}_{20}$ values of the first and second bronchial provocation test did not differ significantly $(\mathrm{P}>.05)$.

Statistically, between the 4 and $8 \mathrm{mg}$ controlled release salbutamol groups, there were no significant differences in the $\mathrm{PC}_{20}$ values of the first and second bronchial provocation test $(\mathrm{P}>.05)$.

The $\mathrm{PC}_{20}$ values of both bronchial provocation test in the 4 and $8 \mathrm{mg}$ controlled release salbutamol groups were shown in table 2.

The $\mathrm{PC}_{20}$ of the first group was $1.24 \pm 1.51 \mathrm{mg} / \mathrm{ml}$ and the PC 20 of the second group was $1.38 \pm 1.65$ $\mathrm{mg} / \mathrm{ml}$. Statistically, there was no significant difference between the two groups $(\mathrm{P}>.05)$.

Treatments with $4 \mathrm{mg}$ controlled release salbutamol for 2 weeks increased the $\mathrm{PC}_{20}$ values from $1.24 \pm 1.51$ to $1.30 \pm 1.18$, and treatments with $8 \mathrm{mg}$ increased the values from $1.38 \pm 1.65$ to $1.81 \pm 1.62$. Statistically, these increases did not differ significantly 
$(P>.05)$. From the run in period to the end of $4 \mathrm{mg}$ and $8 \mathrm{mg}$ controlled release salbutamol treatments, there were increases in $\mathrm{PC}_{20}$ values from $1.24 \pm 1.51$ to $1.88 \pm 1.58$ and from $1.38 \pm 1.65$ to $1.49 \pm 1.71$ respectively. Statistically, both increases did not differ significantly $(\mathrm{P}>.05)$.

A 4 weeks treatment with $4 \mathrm{mg}$ controlled release salbutamol increased the $\mathrm{PC}_{20}$ value to $1.88 \pm 1.58$, while the treatment with $8 \mathrm{mg}$ decreased the value to $1.49 \pm 1.71$. Statistically, the $\mathrm{PC}_{20}$ values at the 4 th week of treatment did not differ significantly from that of the 2 nd week of treatment $(P>0.5)$.

Two weeks after treatment with $4 \mathrm{mg}$ and $8 \mathrm{mg}$ controlled release salbutamol, the $\mathrm{PC}_{20}$ decrease to $1.33 \pm 1.26$ and $1.29 \pm 1.21$ respectively. Between the 2 doses, statistically the decrease in $\mathrm{PC}_{20}$ did not differ significantly $(\mathrm{P}>.05)$.

The changes in $\mathrm{PC}_{20}$ values, in and after treatment with $4 \mathrm{mg}$ and $8 \mathrm{mg}$ controlled release salbutamol were shown in table 3 .

Table 1. Characteristics of the patients

\begin{tabular}{|c|c|c|c|c|c|c|c|c|c|c|}
\hline \multirow[b]{2}{*}{$\begin{array}{l}\text { Patients } \\
\text { number }\end{array}$} & \multirow[b]{2}{*}{ Age } & \multirow[b]{2}{*}{$\begin{array}{l}\text { Sex } \\
M / F\end{array}$} & \multirow[b]{2}{*}{ Weight } & \multirow[b]{2}{*}{ Height } & \multirow[b]{2}{*}{$\begin{array}{c}\text { Reversibility } \\
(\%)\end{array}$} & \multirow[b]{2}{*}{$\begin{array}{c}\text { Before } \\
\text { treatment }\end{array}$} & \multicolumn{3}{|c|}{$\mathrm{FEV}_{1}$} & \multirow[b]{2}{*}{$\begin{array}{l}\text { Illness } \\
\text { duration }\end{array}$} \\
\hline & & & & & & & $\begin{array}{c}\text { 2nd week } \\
\text { of treatment }\end{array}$ & $\begin{array}{c}\text { 4th week } \\
\text { of treatment }\end{array}$ & $\begin{array}{c}2 \text { weeks } \\
\text { after treatment }\end{array}$ & \\
\hline 1 & 22 & F & 45 & 155 & 30.9 & 1680 & 1760 & 1680 & 1480 & 3 years \\
\hline 2 & 21 & $\mathbf{M}$ & 64 & 171 & 27.5 & 2360 & 2570 & 2840 & 3050 & 3 months \\
\hline 3 & 21 & $\mathbf{M}$ & 45 & 150 & 22 & 2000 & 1560 & 1560 & 1720 & 11 years \\
\hline 4 & 24 & $\mathbf{F}$ & 45 & 150 & 29.4 & 1360 & 1680 & 1720 & 1720 & 15 years \\
\hline 5 & 21 & $\mathbf{F}$ & 39 & 153 & 32.5 & 1600 & 2240 & 2000 & 2320 & 2 years \\
\hline 6 & 24 & $\mathbf{M}$ & 47 & 164 & 22.58 & 1240 & 2200 & 2080 & 2280 & 2 years \\
\hline 7 & 36 & $\mathbf{M}$ & 52 & 166 & 35 & 1200 & 2280 & 2240 & 2360 & 3 years \\
\hline 8 & 21 & $\mathrm{~F}$ & 54 & 148 & 21.56 & 2040 & 2440 & 2360 & 2480 & 3 months \\
\hline 9 & 38 & $\mathrm{~F}$ & 64 & 160 & 38.4 & 1560 & 1800 & 1800 & 1880 & 21 years \\
\hline 10 & 16 & $\mathbf{M}$ & 42 & 160 & 20.4 & 1960 & 2520 & 2570 & 2610 & 3 years \\
\hline 11 & 29 & $\mathbf{M}$ & 55 & 162 & 34.37 & 2240 & 2480 & 2340 & 2480 & 9 years \\
\hline 12 & 18 & $\mathbf{M}$ & 47 & 146 & 26.08 & 1840 & 2160 & 2160 & 1880 & 11 years \\
\hline 13 & 45 & $F$ & 82 & 167 & 23.4 & 1880 & 2360 & 2400 & 2400 & 3 months \\
\hline 14 & 17 & $\mathrm{~F}$ & 38 & 151 & 36.8 & 1520 & 2000 & 1800 & 1760 & 2 years \\
\hline 15 & 16 & $\mathrm{~F}$ & 47 & 170 & 25 & 1600 & 2260 & 2000 & 2160 & 1 month \\
\hline 16 & 22 & $\mathbf{F}$ & 48 & 155 & 35.48 & 1240 & 2440 & 1760 & 2160 & 1 year \\
\hline 17 & 17 & $\mathbf{F}$ & 67 & 163 & 29.2 & 2360 & 2810 & 2710 & 2890 & 2 years \\
\hline 18 & 35 & $\mathbf{M}$ & 67 & 169 & 58.82 & 1080 & 2610 & 1080 & 920 & 2 years \\
\hline 19 & 24 & $\mathbf{M}$ & 76 & 179 & 21.97 & 2480 & 2740 & 2850 & 2770 & 3 years \\
\hline 20 & 37 & $\mathbf{M}$ & 45 & 169 & 43.52 & 1700 & 2340 & 2160 & 2120 & 1 year \\
\hline $\begin{array}{l}\bar{X} \\
S D\end{array}$ & $\begin{array}{l}25.2 \\
8.28\end{array}$ & & 53.45 & $\begin{array}{r}160.4 \\
88725\end{array}$ & 30.744 & 1747 & 2262. & 2105 & 2172 & 4.82 \\
\hline SD & 8.28 & & 12.11 & 8.8735 & 9.05098 & 406.06 & 340.4 & 442.3 & 497.228 & 5.60 \\
\hline
\end{tabular}

$\mathrm{M}=$ Male, $\mathrm{F}=$ Female, $\mathrm{FEV}_{1}=$ First minute Forced Expiration Volume 
Table 2. The reproducibility of bronchial provocation test

\begin{tabular}{c|l|l|l|l|l}
\hline \multirow{2}{*}{ Patient } & \multicolumn{2}{|c|}{ SLT 4 mg } & \multicolumn{2}{c|}{ SLT 8 mg } & \multirow{2}{*}{ Significancy } \\
\cline { 2 - 5 } & $\mathrm{PC}_{20}$ I & $\mathrm{PC}_{20}$ II & $\mathrm{PC}_{20}$ I & $\mathrm{PC}_{20} \mathrm{II}$ & \\
\hline & 2.0 & 0.42 & 0.20 & 0.16 & $\mathrm{p}>0.05$ \\
2 & 0.34 & 0.46 & 0.58 & 0.39 & $\mathrm{p}>0.05$ \\
3 & 2.05 & 4.3 & 2.10 & 3.6 & $\mathrm{p}>0.05$ \\
4 & 1.25 & 0.76 & 2.12 & 3.4 & $\mathrm{p}>0.05$ \\
5 & 1.4 & 2.9 & 0.44 & 0.43 & $\mathrm{p}>0.05$ \\
6 & 0.54 & 0.36 & 1.9 & 3.8 & $\mathrm{p}>0.05$ \\
7 & 1.4 & 0.67 & 3.9 & 3.0 & $\mathrm{p}>0.05$ \\
8 & 0.23 & 0.11 & 0.45 & 0.46 & $\mathrm{p}>0.05$ \\
9 & & & 0.14 & 0.04 & $\mathrm{p}>0.05$ \\
10 & & & 0.22 & 0.24 & $\mathrm{p}>0.05$ \\
11 & & & 0.64 & 0.25 & $\mathrm{p}>0.05$ \\
12 & & & 0.55 & 0.28 & $\mathrm{p}>0.05$ \\
\hline $\bar{X}$ & 1.28 & 1.25 & 1.10 & 1.33 & \\
SD & 0.81 & 1.51 & 1.15 & 1.57 & \\
\hline
\end{tabular}

Table 3. The change in $\mathrm{PC}_{20}$ value

\begin{tabular}{l|c|c|c|c|c|c|c}
\hline \multirow{2}{*}{ Time } & \multicolumn{3}{|c|}{ SLT 4 mg } & \multicolumn{3}{c|}{ SLT 8 mg } & Signi- \\
& ficancy \\
& $\mathrm{N}$ & $\overline{\mathrm{X}}$ & $\mathrm{SD}$ & $\mathrm{N}$ & $\overline{\mathrm{X}}$ & $\mathrm{SD}$ & \\
\hline Run in & 8 & 1.24 & 1.51 & 12 & 1.38 & 1.65 & $\mathrm{NS}$ \\
Treatment 1 & 8 & 1.30 & 1.18 & 12 & 1.81 & 1.62 & $\mathrm{NS}$ \\
Treatment 2 & 7 & 1.88 & 1.58 & 12 & 1.49 & 1.71 & $\mathrm{NS}$ \\
Wash out 1 & 8 & 1.33 & 1.26 & 12 & 1.29 & 1.21 & $\mathrm{NS}$ \\
\hline Significancy & \multicolumn{3}{|c|}{$\mathrm{F}=0.3$} & \multicolumn{3}{c}{$\mathrm{F}=0.3$} & \\
& \multicolumn{3}{c|}{$\mathrm{P}>0.05$} & \multicolumn{3}{c}{$\mathrm{P}>0.05$} & \\
\hline
\end{tabular}

The mean of $\mathrm{PC}_{20}$ values of $4 \mathrm{mg}$ and $8 \mathrm{mg}$ controlled release salbutamol groups altogether in the run in period was $1.30 \pm 1.50$, in the second week of treatment the mean was increased to $1.53 \pm 1.37$, while in the 4th week of treatment and 2 weeks after treatment the means were decreased to $1.46 \pm 1.63$ and 1.29 \pm 1.19 respectively. Statistically the increase and decreases in $\mathrm{PC}_{20}$ values did not differ significantly $(P>.05)$ from the value of the run in period.

In the $4 \mathrm{mg}$ controlled release salbutamol group, the $\mathrm{PD}_{20}$ value (a logaritmic conversion of $\mathrm{PC}_{20}$ value) was -0.32 in the run in period; it was increased to -0.04 in the 2 nd week and 0.03 in the 4 th week of treatment respectively, and at 2 weeks after treatment it was decreased to 0.06 . The increase and decrease in the $\mathrm{PD}_{20}$ value was statistically non significant $(\mathrm{P}>0.05)$. The same has occured in the $8 \mathrm{mg}$ group, whose $\mathrm{PD}_{20}$ value was -0.25 in the run in period, -0.13 and -0.10 in the 2 nd and 4 th week of treatment, and -0.18 at 2 weeks after treatment. The increase and decrease in the $\mathrm{PD}_{20}$ value was statistically non significant $(P>.05)$, as was shown in table 4 .

Table 4. The change in $\mathrm{PD}_{20}$ value.

\begin{tabular}{l|c|c|c|c|c|c|c}
\hline \multirow{2}{*}{ Time } & \multicolumn{3}{|c|}{ SLT 4 mg } & \multicolumn{3}{c|}{ SLT 8 mg } & \\
\cline { 2 - 8 } & $\mathrm{N}$ & $\overline{\mathrm{X}}$ & $\mathrm{SD}$ & $\mathrm{N}$ & $\overline{\mathrm{X}}$ & SD & $\begin{array}{l}\text { Signi- } \\
\text { ficancy }\end{array}$ \\
\hline Run in & 8 & -0.32 & 0.36 & 12 & -0.25 & 0.60 & $\mathrm{NS}$ \\
Treatment 1 & 8 & -0.04 & 0.38 & 12 & -0.13 & 0.59 & $\mathrm{NS}$ \\
Treatment 2 & 7 & -0.03 & 0.69 & 12 & -0.10 & 0.48 & NS \\
Wash out 1 & 8 & -0.06 & 0.41 & 12 & -0.18 & 0.56 & NS \\
\hline Significancy & \multicolumn{3}{|c|}{$\mathrm{P}>0.05$} & \multicolumn{3}{c|}{$\mathrm{P}>0.05$} & \\
\hline
\end{tabular}

Statistically, there was no significant difference in $\mathrm{PD}_{20}$ between the $4 \mathrm{mg}$ and $8 \mathrm{mg}$ controlled release salbutamol groups $(\mathrm{P}>.05)$.

The first minute forced expiration volume (FEV $)$ value before treatment was $1747 \pm 406.06 \mathrm{ml}$, it was increased significantly to $2262.5 \pm 340.4$ in the 2 nd week of treatment, then decreased to $2105 \pm 442.3 \mathrm{ml}$ in the 4th week, and increased again to $2172 \pm 497.22$ at 2 weeks after treatment. Statistically the decrease in the $\mathrm{FEV}_{1}$ in the 4 th week of treatment and the increase in the $\mathrm{FEV}_{\mathrm{I}}$ at 2 weeks after treatment did not differ significantly from the $\mathrm{FEV}_{1}$ value in the 2 nd week of treatment $(\mathrm{P}>.05)$.

In all the patients no serious side effect occured during the bronchial provocation test.

\section{DISCUSSION}

The subjects in this study were patients having $\mathrm{FEV}_{1}$ value more than $1000 \mathrm{ml}$ or more than $65 \%$ of the supposed value; this inclusion criterion was used with the aim:

- to avoid the misinterpretation in the $\mathrm{FEV}_{1}$ value which was decreased after the provocation test. Bronchial provocation test was positive when the $\mathrm{FEV}_{1}$ value after the provocation was decrease $20 \%$ or more. When the initial $\mathrm{FEV}_{1}$ value was small, decrease of the value caused by the provocation test was difficult to differentiate from the variability of the $\mathrm{FEV}_{1}$.

- to avoid the subject from heavy airway obstruction, because of the decrease of the FEV 1 after bronchial provocation test. If the initial $F E V_{1}$ is low, after the provocation test it will be lower. 
In the run in period, reversibility test on all the patients showed that the $\mathrm{FEV}_{1}$ was increased more than $20 \%$ after the administration of a bronchodilator. The purpose of this test was to prove that the subject was an asthmatic patient, so that the effect of treatment to reduce bronchial hyperresponsiveness could be assessed.

In this study we used the bronchial provocation test according to Cockroft method, because this method had a standard and could measure bronchial hyperresponsiveness quantitatively. ${ }^{9}$

This method is often used in the Department of Pulmonology, Faculty of Medicine, University of Indonesia/Persahabatan Hospital. ${ }^{8,10-13}$ The metacholine chloride solution as provocative agent is a nonspecific antigen, so that anaphilactic shock will not occur. In the run in period, all the patients in the 4 and $8 \mathrm{mg}$ controlled release salbutamol group were subjected to bronchial provocation test twice. The result was regarded as reproducible when the two provocation test only differed in one concentration of provocative agent. ${ }^{9}$ All the patients showed reproducibility in the provocation test, and statistically between the two provocation test the $\mathrm{PC}_{20}$ values did not differ significantly. This result means that the test was accurate, and the condition of the patients were stable, and were not in exacerbation state. Most of the patients of the two groups were clasified as having mild $\left(\mathrm{PC}_{20}=2-8\right.$ $\mathrm{mg} / \mathrm{ml})$ and moderate $\left(\mathrm{PC}_{20}=0.25-2 \mathrm{mg} / \mathrm{ml}\right)$ bronchial hyperresponsiveness, except subject number 8 in the 4 $\mathrm{mg}$, and subject number 1,9 and 10 in the $8 \mathrm{mg}$ controlled release salbutamol group which were clasified as having heavy bronchial hyperresponsiveness $\left(\mathrm{PC}_{20}\right.$ $=<0.25 \mathrm{mg} / \mathrm{ml}){ }^{9}$

Not as the lung function value, the $\mathrm{PC}_{20}$ values in the two groups were increased during treatment, but this increase was not significant. After the treatment was stopped, the change in $\mathrm{PC}_{20}$ value was also nonsignificant. This result means that this drug has no effect in reducing the bronchial hyperresponsiveness, and this is very much in line with other research which showed that $\beta_{2}$ agonist had no effect in reducing bronchial hyperresponsiveness. ${ }^{4,6,14,15,16}$

In the second week of treatment, in both groups the $\mathrm{FEV}_{1}$ value was increased very significantly compared to the value before tretment. This means that controlled release salbutamol has good effect to the lung function, but can not reduce the bronchial hyperresponsiveness.

Chung et al ${ }^{17}$ showed that salbutamol partly inhibited the bronchoconstriction triggered by platelet activating factor, and had minimal effect in increasing bronchial response after the administration of PAF. This means that 2 agonist does not change the inflama- tion process in the repiratory tract of an asthmatic patient, and the administration along with glucocortocoid inhalation is recomended, especially when the inhalation of $\beta_{2}$ agonist is required to control the symptoms. ${ }^{6}$

$\beta_{2}$ agonist and theophyllin have no or small effect on bronchial hyperresponsiveness and slow phase asthma. ${ }^{2,4,6,14}$ Nevertheless, Davies et al showed that controlled release albuterol increase the median of $\mathrm{PC}_{20}-\mathrm{FEV}_{1}$ before treatment which was $0.153 \mathrm{mg} / \mathrm{ml}$ to $0.29 \mathrm{mg} / \mathrm{ml}$ after a 12 weeks treatment. ${ }^{18}$

Bel et al studied 12 asthmatic patients and 11 COPD (chronic obstructive pulmonary disease) and reported that 2 agonist reduced the respiratory tract hyperresponsiveness to acute bronchoconstrictor stimulations. Salbutamol increased the FEV 1 acutely to $11.5 \%$ of the supposed value in asthma, and to $7.2 \%$ in COPD. The increase in $\mathrm{PC}_{20}$ was 15 folds in asthma, 5 folds in COPD, and did not have protective effect against heavy respiratory tract obstruction caused by strong stimulation. ${ }^{7}$

Higgins et al ${ }^{19}$ reported that the mean of $\mathrm{PC}_{20}$ was changed from 0.80 to $4.75 \mu \mathrm{mol}$ after the administration of salbutamol and from 0.67 to $1.06 \mu \mathrm{mol}$ after the administration of ipratropiumbromide. The increase in $\mathrm{PC}_{20}$ caused by salbutamol was more significant compared to that of ipratropiumbromide (2.26 vs 0.84 , $\mathrm{P}<.05$ ).

Bronchial hyperresponsiveness was slightly but significantly increased by longterm (1 year) salbutamol administration. ${ }^{21,22}$ The increase in bronchial hyperresponsiveness was not due to subsensitisation of $\beta_{2}$ adrenoceptor to salbutamol, but it was due to the failure of $\beta_{2}$ agonist to inhibit the inflamation process underlying the disease. ${ }^{21}$

Bronchodilators does not interfere with the inflamation process, but it fastly eliminates asthmatic symptoms. Administration of bronchodilators could increase the expose of the respiratory tract to alergens, irritants, and agents in the surroundings of the patient. $^{22}$

During the measurements of bronchial hyperresponsiveness no serious side effect had occured, and this was in line with other findings. ${ }^{8,10-13}$

\section{CONCLUSIONS}

1. In the two groups (treated with 4 and $8 \mathrm{mg}$ controlled release salbutamol) the optimal increase in $\mathrm{FEV}_{1}$ occured in the 2 nd week of treatment.

2. Four and $8 \mathrm{mg}$ controlled release salbutamol could increase the $\mathrm{PC}_{20}$ and $\mathrm{PD}_{20}$ value, but statistically the increase were not significant. This means that 
salbutamol does not have effect in reducing bronchial hyperresponsiveness.

3. Measurement of bronchial hyperresponsiveness using metacholine inhalation had no side effect.

\section{Acknowledgment}

We thank PT Glaxo Indonesia who provide us with study drug (vol max).

\section{REFERENCES}

1. American Thoracic Society. Standard for diagnosis and care of Patient with chronic obstructive pulmonary disease (COPD) and Asthma. Am Rev Respir Dis 1987;136:225-44.

2. Barnes PJ. New concept in the pathogenesis of bronchial hyperresponsiveness and asthma. J Allergy C Clin Immunol 1989;83:1013-26.

3. Ronald D, Fairshter. How much theophyline is enough ? Am J Med 1988;85(Suppl 1B); 54-9.

4. Barnes PJ. Inflammatory mechanisms and nocturnal asthma. Am J Med 1988;85(Suppl 1B);64-70.

5. Laitinen LA. Heino A, Laitinen, Kava $T$, Haahtela $T$. Damage of airway epithelium and bronchial reactivity in patients with asthma; Am Rev Respir Dis 1985;131:599606.

6. Tinkelman DG. Clinical management of childhood asthma. PAF and airway hyperreactivity in asthma. Proceeding of symposium. ed by Makinos Taipeh, 1987;28-35.

7. Bel EH, Zwinderman AH, Timmers MC, Dijkman JH, Sterk PJ. The protective effect of beta2 agonist against excessive airway narrowing in response to bronchoconstrictor stimuli in asthma and chronic obstructive lung disease. Thorax 1991;46:9-14.

8. Wiwien HW, Faisal Y, Tamsil S, Hadiarto M. Perbandingan pengukuran hipereaktivitas bronkus antara $\mathrm{PC}_{20}$ dengan peningkatan tahanan jalan napas. MKI 1990;40:560-4.

9. Cockroft DW. Measurement of airway responsiveness to inhaled histamine or metacholine : Methode of continous aerosol generation and tidal breathing inhalation. In Airway
Responsiveness Measurement and Interpretation. ed by. Hargreave FE, Woolcock AJ, Ontario 1985;Astra:22-8.

10. Faisal Y, Hadiarto M, Husaeri F. Pemeriksaan hiperreaktivitas bronkus dengan alat astograph. Laporan pendahuluan. Paru 1987;7:8-12.

11. Raharjo W. Pola reaktivitas bronkus pada penderita penyakit obstruksi saluran napas. Tesis FKUI 1989;42.

12. Yohanes RS. Pengaruh budesonid terhadap hiperreaktivitas bronkus. Tesis FKUI 1989;53.

13. Tamsil S. Efek ketotifen dan budesonid terhadap hiperreaktivitas bronkus pada penderita asthma. Tesis

14. Dutoit JL, Salome CM, Woolcock J. Inhaled corticosteroids reduce the severity of bronchial hyperresponsiveness in asthma but oral theophylline does not. Am Rev Respir Dis 1987;136:1174-8.

15. Wheeler A. A new approach to oral asthma therapy, Jama Sea (Suppl) 1988;2-4.

16. Lipworth BJ. Clark RA, Dhillon DP, Wheeler AWE, Palmer HBD, Mc Devitt DG. Efficacy and side effects of salbutamol controlled release in asthma. Eur Respir J 1989;2(Suppl 5):396s.

17. Lofdhal CG, Chung KF, Long acting 2 adrenoceptor agonist: a new perspective in the treatment of asthma, Eur Respir J $1991 ; 4: 218-26$

18. Davies RJ, Ferguson H, Hetdman MJ, Ollier S, Oral controlled release albuterol. Its effect on asthmatic symptoms and bronchial hyperresponsiveness. Am Rev Respir Dis 1988;137 (4 part 2):32.

19. Higging BG, Powell RM, Cooper S, Tattersfield AE. Effect of salbutamol and ipratropium bromide on airway calibre and bronchial reactivity in asthma and chronic bronchitis. Eur Respir J 1991;4:415-20.

20. Popa V, Beta adrenergic drugs. Clinic in chest medicine 1986;3:313-29.

21. Van Schayck CP, Graafsma SJ, Visch MB, Dompeling E, Van Weel C, Van Herwaarden CLA. Increased bronchial hyperresponsiveness after inhaling salbutamol during 1 year is not caused by subsensitization to salbutamol. J Allergy Clin Immunol 1990;86:793-800.

22. Barnes PJ. A new approach to the treatment of asthma. Drug therapy. Medical intelligence. New Engl J Med 1989;321: 1517-27. 